\title{
Outdoor Thermal Comfort Research in Urban Areas of Central and Southeast Europe: A Review
}

\author{
Jelena Dunjić ${ }^{A}$ \\ Received: December 16, 2019 | Revised: December 29, 2019 | Accepted: December 30, 2019 \\ DOI: $10.5937 / g p 23-24458$
}

\begin{abstract}
Constant urban population growth and intensive urbanization lead to increased pressure on urban areas leading to uncomfortable living conditions. The quality of urban living conditions often depends on the thermal comfort of the open urban spaces, which are used on the daily basis. That is the reason why the attention towards outdoor thermal comfort (OTC) is increasing in the last decade among the researchers from different fields of expertise. In this article, the review of the outdoor thermal comfort research in urban areas of 11 countries of Central and Southeast Europe in the last decade (2010-2019). The main aim of the review is to give a comprehensive, systematic and complete insight in the current situation in the OTC research interest. The results of the review show increased but uneven interest in outdoor thermal comfort by the end of the research period in countries of the Central and Southeast Europe. In total, 120 articles on the topic of outdoor thermal comfort were identified in the research area. The most significant contribution to the urban outdoor thermal comfort research comes from Hungary, Serbia and Greece. Furthermore, five research objectives were identified: methodology improvement and development, climate sensitive and comfortable urban design and planning, citizens/pedestrian comfort and health assessment and improvement, tourism and health sector support and literature review.
\end{abstract}

Keywords: outdoor thermal comfort; urban areas; urban microclimate; urban design; review

\section{Introduction}

Population growth and climate change are probably among the main global issues addressed both by the academic community as well as policy makers nowadays. These issues tend to be more obvious in the urban areas, which offer better career and lifestyle opportunities. However, people are exposed to various types of stress in the urban environment (Gulyás et al., 2006). Population growth increases pressure to the urban environments, due to the expanding demand for living and working space, which sets great challenges to urban design and planning which is supposed to be sustainable, resilient and climate sen- sitive. The awareness of the importance of urban bioclimatic conditions in outdoor environment is ever increasing, especially within the area of urban design and planning in order to contribute to thermally comfortable urban open spaces (Santos Nouri et al., 2018). Urban open spaces largely contribute to the quality of life of the citizens in terms of physical, environmental, social and economic benefits (Lai et al., 2019). Many cities are working on controlling the local climate and microclimate in urban environments in order to reduce heat stress and facilitate better living conditions (Lehnert et al., 2018). Therefore, one

\footnotetext{
A University of Novi Sad, Faculty of Sciences, Department of Geography, Tourism and Hotel Management; Trg Dositeja Obradovića 3, 21000 Novi Sad; e-mail: jelena.dunjic@dgt.uns.ac.rs
} 
of the objectives of the urban design and planning is to improve the attractiveness of the urban open spaces, which could be partly achieved by improving the thermal environment of outdoor spaces (Oke et al., 2017; Lai et al.,2019).

Urban microclimate affects human beings since it determines their comfort sensation (Hoppe, 1999). According to the ASHRAE (2004) human thermal comfort is defined as the perceived and therefore subjective satisfaction with thermal environmental conditions (Hondula et al., 2017). Human thermal comfort can be examined regarding the conditions of the environment and subdivided into indoor and outdoor thermal comfort. Indoor thermal comfort is well examined in the past decades, because of the relative stability and controllability of the indoor environment. On the other hand, outdoor thermal comfort is greatly influenced by variations in the outdoor environment, as well as one's subjective perception (Coccolo et al., 2016).

Increased researchers' attention on outdoor environments started in early 2000's, and ever since a number of studies on outdoor thermal comfort in urban environments worldwide have increased each year, which led to the creation of the significant database (Johansson et al., 2014). This database varies significantly among the countries all over the world.

In this article, the review of the outdoor thermal comfort research in urban areas of Central and Southeast Europe is given in order to provide a comprehensive, systematic and complete insight in the current situation in the OTC research interest. As a starting point, there is an overview of the most frequently used indices and variables for the assessment of urban out- door thermal comfort as well as. The fundamental parameter for assessment of the quality of the urban microclimate is outdoor thermal comfort (Coccolo et al., 2016). The physical variables which affect humans outdoor thermal comfort are: air temperature $\left({ }^{\circ} \mathrm{C}\right)$, wind speed $(\mathrm{m} \cdot \mathrm{s}-1)$, relative humidity $(\%)$, shortwave radiation $(\mathrm{W} \cdot \mathrm{m}-2)$, longwave radiation $(\mathrm{W} \cdot \mathrm{m}-2)$, human activity (met or $\mathrm{W} \cdot \mathrm{m}-2$ ), clothing level (clo) (Coccolo et al., 2016). Coccolo et al. (2016) give an overview of the outdoor thermal indices commonly used in outdoor thermal comfort research (Table 1), and they divide them in three categories of indices:

1. Thermal indices - based on human energy balance, and interrelation between metabolic activities, clothing and environmental parameters;

2. Empirical Indices - define human comfort for a specific climate and are expressed as linear regressions based on the field studies (onsite monitoring and surveys);

3. Indices based on linear equations - define human comfort as a function of the thermal environment and neglecting the microclimate and human behavior.

Besides mentioned indices, The Tourism Climate Index (TCI), should be mentioned, since it is often used for assessing climate conditions and thermal comfort for tourism planning and development. It was developed by Mieczkowski (1985).

Outdoor thermal comfort is quantified with several software packages which are used to determine OTC according to some of the above-mentioned OTC indices (Table 2). The most commonly used software packages are: ENVI-met (and post-processing tool Bi-

Table 1. An overview of the indices commonly used in outdoor thermal comfort research

\begin{tabular}{|c|c|c|}
\hline Thermal Indices & Empirical Indices & Indices based on linear equations \\
\hline COMFA; COMFA + Model & Actual Sensation Vote (ASV) & Apparent Temperature (AT) \\
\hline Universal Effective Temperature (ETU) & Thermal Sensation (TS) & Discomfort Index (DI) \\
\hline Index of Thermal Stress (ITS) & Thermal Sensation Vote (TSV) & $\begin{array}{l}\text { Environmental Stress Index (ESI) and } \\
\text { Physiological Strain Index (PSI) }\end{array}$ \\
\hline MENEX Model & & Effective Temperature (ET) \\
\hline $\begin{array}{l}\text { Physiologically Equivalent Temperature } \\
\text { (PET) }\end{array}$ & & Humidex $(\mathrm{H})$ \\
\hline Predicted Mean Vote $\left(\mathrm{PMV}^{*}\right)$ & & Heat Index (HI) \\
\hline Perceived Temperature (PT) & & Cooling Power Index (PE) \\
\hline $\begin{array}{l}\text { New Standard Effective Temperature } \\
\left(\text { SET }^{*} \text { ) and Outdoor Effective }\right. \\
\text { Temperature (OUT_SET) }\end{array}$ & & Relative Strain Index (RSI) \\
\hline \multirow[t]{2}{*}{ Universal Thermal Climate Index (UTCI) } & & $\begin{array}{l}\text { Wet Bulb Globe Temperature Index } \\
\text { (WBGT) }\end{array}$ \\
\hline & & Wind Chill Index (WCI) \\
\hline
\end{tabular}

* PMV \& SET are originally designed for indoor thermal comfort investigations, but later are adapted for outdoor environment Source: Coccolo et al., 2016 
Table 2. Commonly used software packages for quantifying OTC according to the thermal comfort indices and MRT

\begin{tabular}{|l|c|c|c|c|c|c|c|}
\hline Software & PMV & PET & UTCI & SET & ETU & PT & MRT $^{*}$ \\
\hline ENVI-met \&BioMet & + & + & + & & & & + \\
\hline RayMan & + & + & + & + & & + & + \\
\hline OTC model & & + & + & & + & & \\
\hline SOLWEIC & & + & + & & & & + \\
\hline UTCI calculator & & & + & & & & \\
\hline
\end{tabular}

* MRT is not considered to be a model for quantification OTC, but gives information about pedestrian's thermal perception.

Source: Coccolo et al., 2016

oMet), RayMan, OTC model, SOLWEIG, UTCI calculator.

Most of the reviewed articles used the above-mentioned indices and software packages for quantifying OTC in urban environments. However, this great variety of methods and tools used in the outdoor thermal comfort research makes comparisons difficult (Johansson et al., 2014). According to the Coccolo et al. (2016), not all the indices are suitable for usage in every climate type (Köppen climate classification: tropical, arid, temperate, cold and polar). In temperate climates (which will be discussed in this article), the most frequently used indices are PET, SET and OUT SET; while UTCI is applicable in all climate types.

In this article, the review of the outdoor thermal comfort research in urban areas of 11 countries of Central and Southeast Europe in the last decade (20102019) was performed. The main aim of the review was to give a comprehensive, systematic and complete insight in the current situation in the OTC research interest in the region and to identify the main OTC research objectives and themes.

\section{Study area}

This article covers 11 countries of Central and SouthEast Europe: Hungary, Slovenia, Croatia, Romania, Bulgaria, Serbia, Bosnia and Herzegovina, Montenegro, North Macedonia, Albania and Greece. The largest part of the study area covers the countries of the Balkan Peninsula, except Hungary. Since, there is no universal geographical definition of the area, and it is positioned at the crossroads between South-East and East-Central Europe (Sippel \& Oto, 2014), the study area is defined as Central and South East Europe. According to the basic Köppen climate, the study area belongs to the temperate climate type (Kottek et al., 2006).

\section{Materials and Methods}

The main aim of this article is to provide comprehensive and systematic literature review of the current state of the outdoor thermal comfort research in the countries of Central and South East Europe. For that purpose, several criteria needed to be met in order to make the sources eligible to be taken into consideration. Firstly, only articles published in journals or conferences that concern bioclimate, urban climate, environment, urban planning design and building, were taken into consideration. The articles were gathered from the databases Web of Science, Scopus and Science Direct, as well as the search engine Google Scholar.

This analysis will reveal the progress and the expansion of the outdoor thermal comfort research in the last decade (2010-2019) in the region of Central and South East Europe as a whole, as well as in the particular countries. There is a great variety of the interest in this topic among the investigated countries, and this research tends to give an insight in the research gaps in some of the countries of the study area, as well as to propose further research direction. Since, there are many important climatological events responsible for outdoor thermal comfort especially in urban areas, various keywords were included in the search. The keywords "outdoor thermal comfort", "bioclimate", "urban areas", "urban microclimate", "heat waves", and "cold waves" were combined with the names of the selected countries in order to search for abstracts, titles and keywords of the articles. At the end of the data collection process, the author screened and evaluated all of the collected articles, and then organized and reviewed the most relevant of them. It should be mentioned that 
in the evaluation process, the subjective perception of the author influenced the choice of the relevant articles for detailed review. Therefore, a subjective approach influenced by authors interest, experience and knowledge could be considered as limitation of the study.

\section{Results and Discussion}

\section{Number of articles regarding outdoor thermal comfort in investigated countries}

At the very beginning of the search for the literature regarding OTC in urban areas of Central and South East Europe, the author searched Web of Science for all the articles regarding OTC without stating the study area or the range of the publishing date. Web of Science Core Collection showed 577 results where "outdoor thermal comfort" is within the titles of the articles, where the first of them was published in 2002. Since then there has been a slight increase in the publications until 2010, when the sharper increase in interest in this topic started. Most of the research regarding OTC in urban areas on global level were conducted in China, followed by the USA, Australia, Germany and England. This search for the articles worldwide aimed to give the framework about the global interest in this specific topic. Afterwards, the more specific research was conducted, focusing on the studies from the countries of the study area.
For the analysis of the OTC research in urban areas of the countries of Central and South East Europe the results from Web of Science, Scopus, Science Direct were amplified by the results from Google Scholar. After the initial collection, screening and evaluation process, 120 peer reviewed research articles were chosen and reviewed in order to make systematic and comprehensive overview of the OTC research. The results of the research show increased but uneven interest in outdoor thermal comfort by the end of the research period in countries of the Central and South East Europe (Figure 1).

Research and publication production among the countries of the study area varies significantly. The most significant contribution to the urban outdoor thermal comfort research comes from Hungary, Serbia and Greece. These countries show the most consistency in the publication production in the last decade. The significant number of the research on the OTC in urban areas comes from Romania, but the lack of consist-

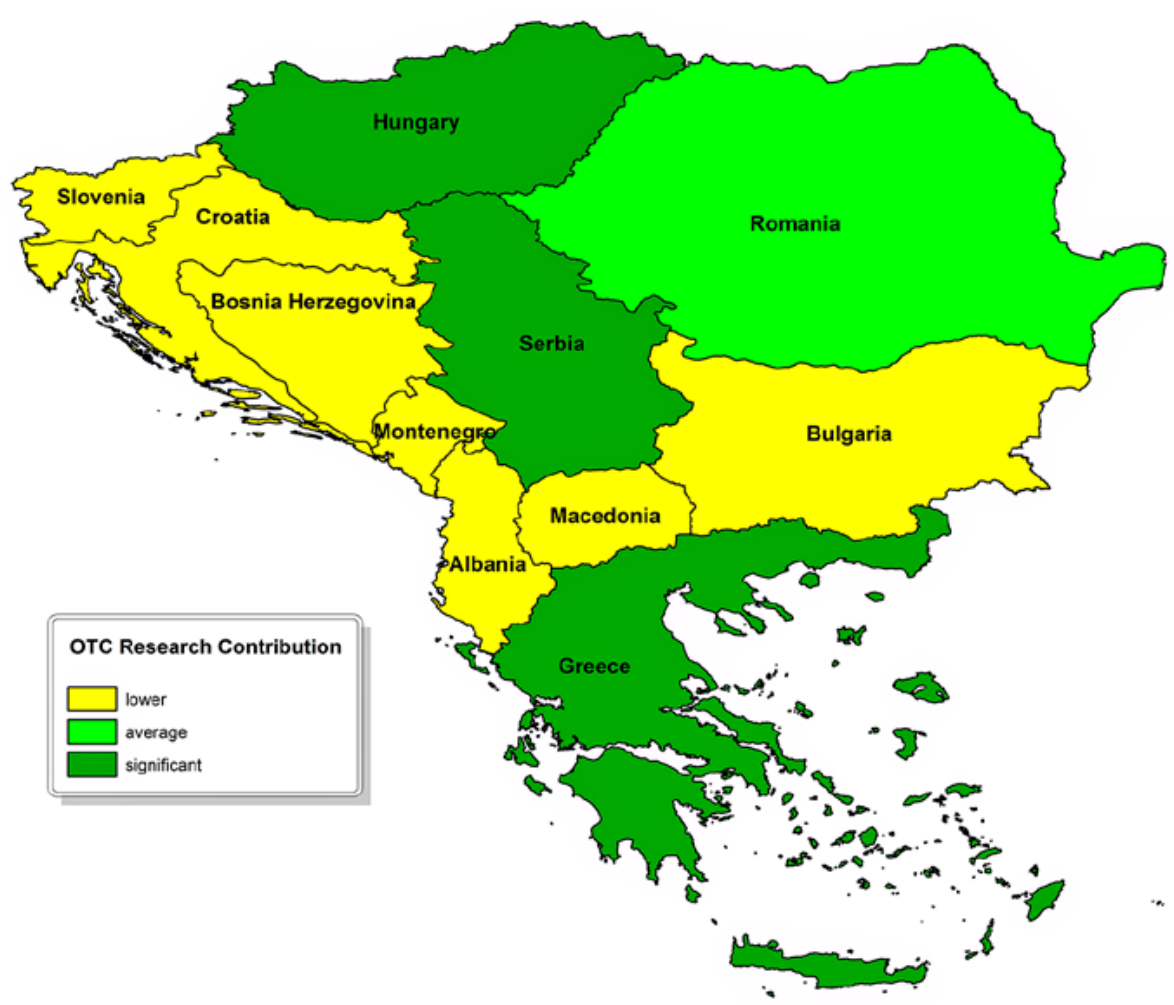

Figure 1. Outdoor thermal comfort research contribution among the countries of the Central and South East Europe (2010-2019)

Source: author based on the reviewed literature 
Table 3. Research production regarding OTC in urban areas of the countries of Central and South East Europe

\begin{tabular}{|c|c|c|}
\hline Country & City/Region & References \\
\hline Albania & Tirana, Durres, Shkodra & $\begin{array}{l}\text { Porja, 2013; Fintikakis et al., 2011; Dervishi et al., 2012; Panariti et al., 2014, } \\
\text { 2015., Malltezi et al., } 2015\end{array}$ \\
\hline $\begin{array}{l}\text { Bosnia and } \\
\text { Herzegovina }\end{array}$ & Neretva Canton, Doboj & $\begin{array}{l}\text { Pecelj et al., 2011; Jahić \& Mezetović, 2014; Trbić et al., 2017; Popov et al., } \\
\text { 2018a; Popov et al., 2018b; Popov et al., } 2019\end{array}$ \\
\hline Bulgaria & Sofia & $\begin{array}{l}\text { Gospodinov \& Tzenkova-Bratoeva, 2010; Malcheva \& Gocheva, 2014; Ivanov } \\
\text { \& Evtimov, 2014; Ivanova, 2016; Malcheva, 2017; Ivanova, } 2017\end{array}$ \\
\hline Croatia & $\begin{array}{l}\text { Hvar, Osijek, Rijeka, Zagreb, } \\
\text { Split }\end{array}$ & Zaninovic, 2011, 2013; Zaninović \& Matzarakis, 2014; Brosy et al., 2014 \\
\hline Greece & $\begin{array}{l}\text { Athens, Serres, Arta, } \\
\text { Heraklion, Volos }\end{array}$ & $\begin{array}{l}\text { Theoharatos et al., 2010; Pantavou et al., 2011; Giannaros \& Melas, } \\
\text { 2012; Dimoudi et al., 2012; Nastos \& Mazarakis, 2012, 2013; Zoras, 2013; } \\
\text { Charalampopoulos, 2013; Pantavou et al, 2013; Dimoudi et al., 2014; Founda } \\
\text { et al., 2015, 2017; Bleta \& Nastos, 2015; Papamanolis, 2015; Chatzidimitriou } \\
\text { \& Yannas, 2016; Nastos et al., 2016; Nastos \& Polychroni, 2016; Paravantis } \\
\text { et al., 2017; Dimitris et al., 2017; Moustris et al., } 2018\end{array}$ \\
\hline Hungary & Szeged, Budapest, Pecs & $\begin{array}{l}\text { Gulyás et al., 2010; Kántor \& Unger, 2010, 2011; Kovács \& Németh, 2012; } \\
\text { Kántor et al., 2012a; 2012b; Vitt et al., 2015; Unger et al., 2015; Kántor et al., } \\
\text { 2016a, 2016b, 2016c; Takács et al., 2016a, 2016b; Skarbit et al., 2017; Gál, } \\
\text { 2018; Unger et al., 2018; Kántor et al., } 2018\end{array}$ \\
\hline $\begin{array}{l}\text { North } \\
\text { Macedonia }\end{array}$ & Skopje & $\begin{array}{l}\text { Kendrovski et al., 2011; WHO, 2011; Glavinov, 2012; Kendrovski et al., 2014; } \\
\text { Bislimovska, 2015; Martinez et al., 2016; Kaplan et al, } 2018\end{array}$ \\
\hline Montenegro & $\begin{array}{l}\text { Herceg Novi, Podgorica, } \\
\text { Ulcinj }\end{array}$ & $\begin{array}{l}\text { Joksimović et al., 2013; Burić et al., 2014; Doderović \& Burić, 2015; Burić et } \\
\text { al., 2015; Bajçinovci, } 2017\end{array}$ \\
\hline Romania & $\begin{array}{l}\text { Bucharest, Craiova, Cluj- } \\
\text { Napoca }\end{array}$ & $\begin{array}{l}\text { Ionac et al., 2012a, 2012b; Croitoru \& Piticar, 2013; Cheval \& Dumitrescu, } \\
\text { 2014; Cheval et al., 2015; Dragota \& Havris, 2015; Marques et al., 2015; } \\
\text { Papathoma-Koehle et al., 2016; Croitoru et al., 2016; Herbel et al., 2016; } \\
\text { Teodoreanu, 2016; Udristioiu et al., 2017; Ciupertea et al., 2017; Cheval et al., } \\
\text { 2017; Piticar et al., 2018; Velea et al., 2019; Mihăilă et al., 2019. }\end{array}$ \\
\hline Serbia & $\begin{array}{l}\text { Novi Sad, Niš, Belgrade, } \\
\text { Leskovac }\end{array}$ & $\begin{array}{l}\text { Malinovic-Milicevic et al., 2013; Unkašević \& Tošić, 2013, 2015; Savić et } \\
\text { al., 2014, 2016, 2018; Stanojević et al., 2014a; 2014b; Šećerov et al., 2015; } \\
\text { Bajšanski et al., 2015; Milošević et al, 2015a, 2015b, 2016, 2017a, 2017b; } \\
\text { Djukic et al., 2016; Anđelković et al., 2016; Basarin et al, 2016, 2018; } \\
\text { Bogdanović-Protić et al., 2016; Djekic et al., 2018a, 2018b; Vučković et al, } \\
\text { 2019, Lukić et al., } 2019\end{array}$ \\
\hline Slovenia & Ljubljana & $\begin{array}{l}\text { Vidrih \& Medved, 2013; Fikfak et al., 2017; Pogačar et al., 2017, 2019a, 2019b; } \\
\text { Perčič et al., 2018; Žiberna \& Ivajnšič, } 2018\end{array}$ \\
\hline
\end{tabular}

ency in the research is noticeable too. In other countries of the study area, the research of the OTC in urban areas is at its initial phase, and often a part of the other climate or bioclimate research (Table 3 ).

According to the research production regarding OTC in urban areas of the countries of Central and South East Europe, the author noticed three groups of countries: countries with significant, average and low interest and consequently research article production. Serbia, Hungary and Greece show significant interest in the topic, Romania - average, and all other countries lowinterest in the topic.

\section{Countries with significant OTC research production}

HUNGARY is one of the pioneers in the OTC research in this part of the world (CSEE). Therefore, the research results regarding OTC are numerous and significant. Their significance and relevance are results of persistence and systematic approach to the re- search. Many of the topics regarding OTC were covered by the researchers from Hungary.

Some of the authors worked on the OTC research methodology development and improvement. For example, Kántor \& Unger (2010a) recommended a methodology for the thermal comfort investigations of resting places (parks and squares) in urban environments by marking subjects' exact location, as well as observing some of their personal features, and presenting the results on the maps. Kántor (2016b) asserts the importance of questionnaire-based OTC investigations, besides traditional and well-established thermal comfort indices. Gál (2018) systematically assessed the reliability of the popular microclimate models (SOLWEIG v2016a, RayMan Pro v3.1 and ENVI-met v4.3) and their ability to reproduce Tmrt in complex urban environments. Skarbit et al. (2017) used urban monitoring network to monitor air temperature conditions in different LCZs of Szeged. 
Measurements and assessment of thermal comfort and other climatological events responsible for outdoor thermal comfort were also investigated. Kovács \& Németh (2012) evaluated the differences and changes of the thermal comfort conditions in the last half century in Budapest based on the measurements of two meteorological stations located in different environments (LCZs). Kántor et al. (2012a) investigated interrelationships of subjective assessments-thermal sensation, perceptions and preferences for individual climate parameters, as well as their connections with the prevailing thermal conditions. Kántor et al. (2012b) expanded their investigation (2012a) by comparing the results from Szeged with the international results with the similar methodology (combination of survey and on-site measurements). Kántor et al. (2016c) investigated seasonal differences in subjective assessment of the thermal conditions in Szeged in spring, summer and autumn season.

These research are strongly connected and contribute to the research of climate sensitive urban design. Unger et al. (2015) discussed the infrastructure development and operation of an urban human comfort monitoring network and information system in Szeged and the related preliminary research results. Kántor et al. (2016a) provide evidence on the beneficial micro-meteorological modification effect of large urban trees with an emphasis on their human-biometeorological effects, and propose landscape design solutions for summertime thermal stress mitigation. Takács et al. (2016a, 2016b) investigated the importance of the urban greenery (different tree species commonly present in Hungary) and their shading effect in achieving thermally comfortable outdoor spaces in urban areas. Unger et al. (2018) evaluated outdoor human thermal sensation in different urban quarters (local climate zones) of Szeged, according to the long-term data. Gulyás et al. (2010) made a comparison of the urban-rural comfort sensation in Szeged. Kántor et al. (2018) examined the effectiveness of the shading methods (natural and artificial) in achieving comfortable thermal conditions at three different locations of Pecs. Vitt et al. (2015) estimated and compared thermal conditions in urban and rural environments of Szeged, in order to contribute to tourism planning.

Important review on the topic of the mean radiant temperature $T_{m r}$, as the most important parameter influencing outdoor thermal comfort during sunny conditions was provided by Kántor \& Unger (2010b). These authors gave a review on the topic of the mean radiant temperature $T_{m r t}$, as the most important parameter influencing outdoor thermal comfort during sunny conditions.

After reviewing the most significant research from Hungary from the last decade, it might be conclud- ed that investigations regarding OTC are well established with numerous topics covered.

Initial urban climate research in SERBIA covered the topics regarding thermal stress, local climate zones, monitoring system, thermal comfort etc. (Savić et al., 2013; Savić et al., 2014, Lelovics et al., 2016). In the last decade, publication production increased, constantly and consistently.

Methodology development and assessment were discussed in several articles from Serbia. Šećerov et al. (2015) presented the process of development and implementation of an automated urban climate monitoring system in Novi Sad, which consists of 27 stations (25 in urban area and 2 in non-urbanized environment. Milošević et al. (2015a, 2015b, 2016) investigated the suitability of urban climate monitoring systems developed in Novi Sad for human comfort assessment in various areas of the city and surroundings which differ in density of construction. Bajšanski et al. (2015) presented innovative software solutions and tools for assessment and improvement of human OTC in urban built environment, which combines $3 \mathrm{D}$ modeling, parametric design and environmental analysis. Milošević et al. (2017) applied the mentioned software solutions for analysis of the OTC at the parking lots during the summer heat wave. Anđelković et al. (2016) proposes one new attempt to formulate a mathematical approach to climate parameters in the context of their complex implications for tourist activities through the tourism climate comfort index (TCCI). Bogdanović-Protić et al. (2016) developed and applied the ELM algorithm (extreme learning machine) for forecasting OTC index - physiological equivalent temperature values in urban open space of Niš fortress.

Some of the authors focused on measurements and assessment of citizens thermal comfort and other climatological aspects influencing outdoor thermal comfort. Basarin et al. (2016) analyzed heat and cold waves and human thermal conditions in Novi Sad, Serbia in the period 1949-2012. Extreme bioclimatic conditions in Vojvodina were analysed as well by Basarin et al. (2018). Unkašević and Tošić investigated cold and heat waves in Serbia (2015), as well as trends in temperature indices (2013). Summer discomfort in Niš was assessed using Humidex index by Lukić et al. (2019). Malinović-Milićević et al. (2013) assessed thermal environment and UV-B radiation in Vojvodina region, while Stanojević et al. (2014a, 2014b) investigated heat wave impact on mortality and the necessity for heat health warning system.

Some of the research contributed to the development of climate sensitive outdoor spaces. Djukić et al. (2016) presented the change in the outdoor comfort during the summer days of open public space of the 
main square in Leskovac. Djekić et al. (2018a) focused on physical attributes of used pavement materials and their impact when they are exposed to high summer temperatures as well as on thermal comfort of the users of open public spaces in Niš. Djekić et al. (2018b) analyse the influence of urban greenery on temperature reduction by measuring the difference in warming up of grassy surfaces and paving materials commonly used for public areas and evaluating the impact of tree shading on the surface cooling during the day. Vučkovič et al. (2019) tend to determine and rank the parameters which have the most influence on thermal comfort variations in urban public areas in several cities in Serbia using PET as the thermal comfort indicator, and neuro-fuzzy methodology for PET analyzing.

Savić et al. (2016) presented the review of the research of urban climate in Novi Sad (Serbia) between 2011 and 2016.

Research of the OTC in Serbia in the last decade is well established and is interesting for the researchers from various fields of expertise.

GREECE is the third country from the study area with significant OTC research production. Different aspects of thermal comfort were examined in the last decade.

Methodology development and assessment were the objectives of some of the reviewed articles. Zoras (2014) performed software simulation of the different pavement materials and their influence on the thermal conditions in the densely built area of the city centre of Arta. Moustris et al. (2018) worked on the development and application of artificial neural network models (ANNs) to estimate the values of a complex human thermal comfort-discomfort index associated with urban heat and cool island conditions inside various urban clusters using only inputs air temperature data from a standard meteorological station.

Citizens comfort and health assessment were assessed by many authors. Theoharatos et al. (2010) investigated heat waves observed in 2007 in Athens and their impact on citizens health conditions. Pantavou et al. (2011) evaluated the impact of the heat wave thermal stress on the increase of the daily number of patients probably affected by heat in emergency department units of cardiac clinics of four public general hospitals in Athens. Dimoudi et al. (2012) analyzed wind speed and air temperatures in the central urban area (urban canyons) of the Serres City in North Greece, and the influence of the built environment on thermal comfort and UHI effect compared to the suburban area of the same city. UHI effect in Thessaloniki was investigated by Giannaros \& Melas (2012). Heat waves and UHI effect were also examined in Athens by Founda et al. $(2012,2017)$.
Nastos \& Mazarakis (2012) estimated the effect of air temperature and human thermal indices on mortality in Athens. Mortality associated with heat waves were investigated by Paravantis et al. (2017). Pantavou et al. (2013) conducted combined meteorological measurement and field survey among pedestrians in three locations in Athens, during summer, autumn and winter season, in order to assess individual thermal sensation of the pedestrians. Bleta \& Nastos (2015) assessed and quantified the association between present and future human thermal bioclimatic conditions and daily cases with respiratory problems in Heraklion city on Crete, Greece.

Research contribution to climate sensitive urban design and assessment is noticed too. Charalampopoulos et al. (2013) analyzed thermal bioclimatic conditions in six urban areas of Athens during summer. Nastos \& Mazarakis (2013) and Nastos \& Polychroni (2016) analyzed bioclimatic conditions in the University campus of Athens. Dimoudi et al. (2014) investigated the thermal behavior of construction materials inside an urban centre and the improvement of thermal conditions induced by replacement of conventional with cool materials. Papamanolis (2015) investigated main characteristics of the built environment, urban climate and the air quality in Greek cities.Chatzidimitriou \& Yannas (2016) investigated the influence of urban morphology and urban design parameters such as street and building geometry, landscape elements including vegetation types, water surfaces and material properties and their effects on pedestrian thermal comfort in cities. Dimitris et al. (2017) used Computational Fluid Dynamics (CFD) to assess the improvement of microclimate conditions in an urban agglomeration of the city of Volos, through bioclimatic interventions.

Nastos et al. (2016) investigated long-term seasonal behavior of the climate for touristic activities and recreation.

From the previous review it could be concluded that these three countries of Central and South East Europe indeed have great variety of research topics regarding OTC, with significant relevance and applicative results.

\section{Countries with average OTC research production}

In this category there is only one country - RomANIA. Not all of the research from Romania is narrowly focused on OTC assessment, some of them indirectly concern OTC conditions in urban areas.

Most of the research was focused on various aspects of citizens comfort and health conditions. Heat waves and extreme temperatures were investigated by several authors (Ionac et al., 2012a; 2012b; Croitoru \& Piticar, 2013; Dragota \& Havris, 2015; Croitoru et al., 2016; Ciu- 
pertea et al., 2017; Piticar et al., 2018), as well as the UHI effect. Cheval and Dumitrescu (2014) and Cheval et al. (2015) presented the first results from the enhanced network for UHI monitoring in Bucharest. Herbel et al. (2016) assessed UHI in Cluj-Napoca city. Marques et al. (2015) performed heat stress assessment of two contrasted outdoor urban environments in two European capitals - Bucharest and Lisbon in order to examine thermal physiological response to heat stress and to quantify the effect of urban green spaces. Teodoreanu (2016) reviewed some bioclimatic indices, based on several different meteorological parameters, for various purposes - health, tourism, regionalization. Udristioiu et al. (2017) tried to examine UHI effect in Craiova city, using satellite-based data (land surface temperature - LST, and land cover type-LCT) and to assess its intensity during summer. In 2017 Cheval et al. conducted the research where eight Thermal Comfort Indices were computed and statistically analysed (individually and combined). Valea et al. (2019) investigated the possibility to supplement the information on the summer thermal discomfort conditions in Romania by using the NET index derived from a long-term (1971-2000) gridded station-based dataset and compare the results of two approaches with the information provided by the operationally used Temperature-Humidity index.

Methodology for heat wave risk assessment was investigated by Papathoma-Koehle et al. (2016).

Mihăilă et al. (2019) investigated bioclimatic conditions of the five representative balneary-climatic resorts, located in three different bioclimatic zones.

The research from Romania regarding OTC in the last decade is increasing but there is an obvious lack of consistency which indicates that future research regarding OTC should be conducted with a more systematic approach.

\section{Countries with low OTC research production}

Albania, Bosnia \& Herzegovina, Bulgaria, Croatia, Montenegro, North Macedonia, Slovenia are the countries with less than 10 published research articles in the last decade regarding OTC.

In Albania, Fintikakis et al (2011) analysed micro-climatic conditions in the historic centre of Tirana with the aim to provide information for better design of specific open spaces. Dervishi et al. (2012) examined thermal conditions in four urban zones of Tirana, according to meteorological data, combined with interviews with citizens. Porja (2013) assessed heatwaves in Tirana. Panariti et al. $(2014,2015)$ evaluated the impact of the texture of the paving materials on OTC, at the coastal promenade in the city of Durres. Malltezi et al. (2015) assessed climate change adaptation strategies in Tirana.
The OTC research from Bosnia \& Herzegovina mainly focus on the examination of climate potential for tourism development in eight destinations of Neretva Canton (Jahić \& Mezetović, 2014), and in Doboj (Pecelj et al., 2011). Air temperature and its extremes were investigated by several authors (Trbić et al., 2017; Popov et al., 2018a, 2018b, 2019).

OTC research in BULGARIA is focused on the winter thermal comfort (Gospodinov \& Tzenkova-Bratoeva, 2010; Malcheva \& Gocheva, 2014, Malcheva, 2017), unlike the research from other countries, where the majority of the articles are focused on the heat waves and OTC assessment in warmer periods. Extreme temperature risks and heat risks in Bulgaria were investigated by Ivanov \& Evtimov (2014) and Ivanova $(2016,2017)$.The research articles of indoor thermal comfort are much more frequent in Bulgaria.

The research regarding OTC in CROATIA is not very developed. There are some studies regarding bioclimate in Croatia (e.g. Zaninović \& Matzarakis 2014), extreme thermal conditions (Zaninović, 2011) or climatological effects on tourism (Zaninović, 2013; Brosy et al., 2014), but according to this research database, none of them concerns OTC specifically.

Similar situation with MonTeneGro, where research articles are not specifically focused on OTC, but it is mentioned in some of the articles regarding climatological aspect of tourism seasonality and development (Joksimović et al., 2014) and urban design and sustainable development (Bajçinovci, 2017), as well as air temperature changes and extreme events (Burić et al., 2014; Doderović \& Burić, 2015; Burić et al., 2015).

In North Macedonia, research articles are focused on climate vulnerability (Glavinov, 2012), UHI analysis (Kaplan et al., 2018) and the impact of the climatic conditions on human health (Kendrovski et al., 2011; WHO, 2011; Kendrovski et al., 2014; Bislimovska, 2015; Martinez et al., 2016), but there are no specific studies on the OTC.

Research articles regarding specifically OTC in SLOvenia are not very common in the literature from Slovenia. However, there are some articles regarding other aspects of bioclimate, where OTC is indirectly assessed. For example, the articles regarding UHI mitigation (Vidrih \& Medved, 2013; Fikfak et al., 2017), heat stress and mortality and health issues (Pogačar et al., 2017; 2019a; 2019b; Perčič et al., 2018; Žiberna \& Ivajnšič, 2018). On the other hand, indoor thermal comfort and energy efficiency is more com- 
mon topic of interest among Slovenian researchers in the last decade (Pajek \& Košir, 2017; 2018; Pajek et al., 2019)

There is an obvious lack of systematic approach and consistency when it comes to the OTC research on the country level within the countries with the low OTC research production. There are sporadic attempts to investigate this topic, but there is still a general lack of this type of research, even though the obvious need for it exists.

\section{Conclusion}

The review of the literature regarding OTC in the last decade implicates its applicability in urban design and planning, tourism, and health issues. There were many different objectives and themes in the reviewed articles. In order to make the review clearer and more systematic, majority of the mentioned research objectives could be divided to the following groups:

1. Methodology (database, software, algorithm, systems) improvement and development

2. Climate sensitive and comfortable urban design and planning,

3. Citizens/pedestrian comfort and health assessment and improvement,

4. Tourism and health sector support,

5. Literature review.

When it comes to the indices used in the reviewed research, it must be noted that not all of the reviewed articles used some of the OTC indices or software. The methodology is strongly dependent to the research objectives and available data. In the articles that used thermal indices, the absolutely dominant index is PET, followed by UTCI, but Tourism Climate Index (TCI) should be mentioned too, since a lot of researchers of Mediterranean cities used it for their studies. Mean radiant temperature was also examined in terms of methodology development, as well as the significant indicator for OTC assessment.

The most commonly used software packages for quantifying OTC according to the thermal comfort indices and MRT in the reviewed articles are RayMan software, followed by the ENVI-met. In some articles a combination of questionnaire surveys and meteorological measurements was applied in order to examine subjective thermal sensations. Urban public green spaces (such as parks), streets, squares, parking lots and sidewalks were the most frequently selected locations for measurements and questionnaire surveys. The majority of the articles focused on outdoor thermal comfort were related with urban design assessments, as well as proposals for improvement with the main objective of achieving sustainability and improvement of the quality of life in urban areas.

The interest for the outdoor thermal comfort conditions began in the early 20oos. Since then steady increase was noticed until 2010, when the more dynamic increase in the production of the scientific publications where the topic of interest is particularly OTC. Its importance in measurement, estimation and improvement of thermal conditions in densely populated urban areas is recognized and therefore more frequently studied. In this study, two major conclusions were achieved, regarding publication productivity and the research interest in OTC in the countries of Central and South East Europe, and identification of five main research objectives in assessment of the OTC.

In the countries of Central and South East Europe, in the last decade, the research publication production regarding OTC increased significantly. That increase is not balanced between all of the countries taken into account in this study. Some of them have significant scientific research results on this topic such as Hungary, Serbia and Greece, with more than 20 published scientific articles during the last decade. Romanian researchers published several studies on different aspects of OTC, but there is still lack of consistency in this topic research. In other seven examined countries, there are sporadic initiatives towards OTC research, but there is evident lack of systematic approach, as well as continuity in the research process.

During the review process, five main research objectives were identified: methodology (database, software, algorithm, systems) development and assessment, climate sensitive and comfortable urban design and planning, citizens/pedestrian comfort and health assessment and improvement, tourism and health sector support, and literature review. All of the reviewed articles set at least one of the objectives from these five groups.

As many authors before (e.g. Johansson et al., 2014), during the reviewing of the 120 articles which were taken into consideration in this review, the inconsistency in the research process appeared as the main obstacle. There is a great variety of the indices, software, field surveys, measurements duration, objectives and expectations from the measurements and surveys, that make systematization of the results challenging. In that regard, this review paper brought forward the OTC research in Central and Southeast Europe with all of its objectives, themes, trends and country differences which can be beneficial for the researchers in the region and worldwide. 


\section{Acknowledgement}

This research is supported by the project grant from the Ministry of Education, Science and Technological Development of the Republic of Serbia through the Project No. 176020, and Provincial Secretariat for Higher Education and Scientific Research, Autonomous Province of Vojvodina (Project No.142-451-2512/2019-01).

\section{References}

Anđelković, G., Pavlović, S., Đurđić, S., Belij, M., \& Stojković, S. (2016). Tourism climate comfort index (TCCI)-an attempt to evaluate the climate comfort for tourism purposes: the example of Serbia. Global NEST Journal, 18(3), 482-493.

ASHRAE (2004). Standard 90.1-2004, Energy standard for buildings except low rise residential buildings. American Society of Heating, Refrigerating and Air-Conditioning Engineers, Inc.

Bajçinovci, B. (2017). Achieving thermal comfort and sustainable urban development in accordance with the principles of bioclimatic architecture: A case study of Ulcinj (Montenegro). Quaestiones Geographicae, 36(4), 131-140.

Bajšanski, I. V., Milošević, D. D., \& Savić, S. M. (2015). Evaluation and improvement of outdoor thermal comfort in urban areas on extreme temperature days: Applications of automatic algorithms. Building and Environment, 94, 632-643.

Basarin, B., Lukić, T., \& Matzarakis, A. (2016). Quantification and assessment of heat and cold waves in Novi Sad, Northern Serbia. International journal of biometeorology, 6o(1), 139-150.

Basarin, B., Lukić, T., Mesaroš, M., Pavić, D., Đorđević, J., \& Matzarakis, A. (2018). Spatial and temporal analysis of extreme bioclimate conditions in Vojvodina, Northern Serbia. International Journal of Climatology, 38(1), 142-157.

Błażejczyk, K., Baranowski, J., Jendritzky, G., Błażejczyk, A., Bröde, P., \& Fiala, D. (2015). Regional features of the bioclimate of central and southern Europe against the background of the KöppenGeiger climate classification. Geographia Polonica, 88(3), 439-453.

Bleta, A., \& Nastos, P. (2015). Present and Future Human Thermal Bioclimatic Conditions and Impacts on Respiratory Admissions in Crete Island, Greece. In EGU General Assembly Conference Abstracts (Vol. 17).

Bogdanović-Protić, I. S., Vukadinović, A. V., Radosavljević, J. M., Alizamirc, M., \& Mitković, M. P. (2016). Forecasting of outdoor thermal comfort index in urban open spaces: The Nis fortress case study. Thermal Science, 20(5), 1531-1539.
Brosy, C., Zaninovic, K., \& Matzarakis, A. (2014). Quantification of climate tourism potential of Croatia based on measured data and regional modeling. International journal of biometeorology, 58(6), 1369-1381

Burić, D., Luković, J., Ducić, V., Dragojlović, J., \& Doderović, M. (2014). Recent trends in daily temperature extremes over southern Montenegro (1951-2010). Natural Hazards and Earth System Sciences, 14(1), 67-72.

Burić, D., Ducić, V., Mihajlović, J., Luković, J., \& Dragojlović, J. (2015). Recent extreme air temperature changes in Montenegro. Bulletin of the Serbian geographical society, 95(4), 53-66.

Charalampopoulos, I., Tsiros, I.,Chronopoulou-Sereli, A., \& Matzarakis, A. (2013). Analysis of thermal bioclimate in various urban configurations in Athens, Greece. Urban Ecosystems, 16(2), 217-233.

Chatzidimitriou, A., \& Yannas, S. (2016). Microclimate design for open spaces: Ranking urban design effects on pedestrian thermal comfort in summer. Sustainable Cities and Society, 26, 27-47.

Cheval, S., \& Dumitrescu, A. (2014). The summer urban heat island of Bucharest (Romania) as retrieved from satellite imagery. In EGU General Assembly Conference Abstracts (Vol. 16).

Cheval, S., Lucaschi, B., Ioja, C., Dumitrescu, A., Manea, A., Radulescu, A., Dumitrache, C., Tudorache, G., Vanau, G., \& Onose, D. (2015). Monitoring the urban heat island of Bucharest (Romania) through a network of automatic meteorological sensors-first results. In EGU General Assembly Conference Abstracts (Vol. 17).

Cheval, S., Ciobotaru, A. M., Andronache, I., \& Dumitrescu, A. (2017). Monitoring and assessment of the outdoor thermal comfort in Bucharest (Romania). In EGU General Assembly Conference Abstracts (Vol. 19, p. 14545).

Ciupertea, A. F., Piticar, A., Djurdjevic, V., Croitoru, A. E., \& Bartok, B. (2017). Future Changes In Extreme Temperature Indices In Cluj-Napoca, Romania. Aerul si Apa. Componente ale Mediului, 235242.

Coccolo, S., Kämpf, J., Scartezzini, J. L., \& Pearlmutter, D. (2016). Outdoor human comfort and ther- 
mal stress: A comprehensive review on models and standards. Urban Climate, 18, 33-57.

Croitoru, A. E., \& Piticar, A. (2013). Changes in daily extreme temperatures in the extra-Carpathians regions of Romania. International Journal of Climatology, 33(8), 1987-2001.

Croitoru, A. E., Piticar, A., Ciupertea, A. F., \& Roşca, C. F. (2016). Changes in heat waves indices in Romania over the period 1961-2015. Global and planetary change, 146, 109-121.

Dervishi, S., Lacaj, E., \& Vathi, R. (2012). Urban heat islands (UHI) mitigation in densely urban city of Tirana, Albania: Materials, energy, comfort. International Journal of Business and Technology, 1(1), 48-57.

Dimoudi, A., Kantzioura, A., Zoras, S., \& Kosmopoulos, P. (2012). The influence of urban design in microclimate inside the urban canyons. ICUC $8-8$ th International Conference on Urban Climates, 6th1oth August, 2012, UCD, Dublin Ireland.

Dimoudi, A., Zoras, S., Kantzioura, A., Stogiannou, X., Kosmopoulos, P., \& Pallas, C. (2014). Use of cool materials and other bioclimatic interventions in outdoor places in order to mitigate the urban heat island in a medium size city in Greece. Sustainable Cities and Society, 13, 89-96.

Dimitris, F., Catherine, B., Aris, T., Thomas, B., \& Constantinos, K. (2017). CFD Study of Thermal Comfort in Urban Area. Energy and Environmental Engineering, 5(1), 8-18.

Doderovic, M. M., \& Buric, D. B. (2015). Atlantic Multi-Decadal Oscillation And Changes Of Summer Air Temperature In Montenegro. Thermal Science, 19(2), 405-414.

Dragota, C. S., \& Havris, L. E. (2015). Changes in Frequency, persistence and intensity of extreme hightemperature events in the Romanian Plain. Aerul si Apa. Componente ale Mediului, 17.

Djekic, J., Djukic, A., Vukmirovic, M., Djekic, P., \& Brankovic, M. D. (2018a). Thermal comfort of pedestrian spaces and the influence of pavement materials on warming up during summer. Energy and Buildings, 159, 474-485.;

Đekić, J. P., Mitković, P. B., Dinić-Branković, M. M., Igić, M. Z., Đekić, P. S., \& Mitković, M. P. (2018b). The study of effects of greenery on temperature reduction in urban areas. Thermal Science, 22(4), 9881000.

Djukic, A., Vukmirovic, M., \& Stankovic, S. (2016). Principles of climate sensitive urban design analysis in identification of suitable urban design proposals. Case study: Central zone of Leskovac competition. Energy and Buildings, 115, 23-35.

Gál, C. V. (2018). Modeling mean radiant temperature in outdoor spaces, A comparative numerical sim- ulation and validation study. In 1oth International Conference on Urban Climate jointly with 14th Symposium on the Urban Environment, New York, NY, USA, 6-10 August 2018.

Giannaros, T. M., \& Melas, D. (2012). Study of the urban heat island in a coastal Mediterranean City: The case study of Thessaloniki, Greece. Atmospheric Research, 118, 103-120.

Gospodinov, I., \& Tzenkova-Bratoeva, A. (2010). Spatial and temporal variability of the rate of change of the winter thermal comfort conditions in Bulgaria. Berichte des Meteorologischen Instituts der AlbertLudwigs-Universität Freiburg, 195.

Gulyás, Á., Unger, J., \& Matzarakis, A. (2006). Assessment of the microclimatic and human comfort conditions in a complex urban environment: modelling and measurements. Building and Environment, 41(12), 1713-1722.

Gulyás, Á., Matzarakis, A., \& Unger, J. (2010). Comparison of the urban-rural comfort sensation in a city with warm continental climate. Berichte des Meteorologischen Instituts der Albert-Ludwigs-Universität Freiburg, 20, 473-478.

Herbel, I., Croitoru, A. E., Rus, I., Harpa, G. V., \& Ciupertea, A. F. (2016). Detection of atmospheric urban heat island through direct measurements in Cluj-Napoca city, Romania. Hungarian Geographical Bulletin, 65(2), 117-128.

Hondula, D. M., Balling, R. C., Andrade, R., Krayenhoff, E. S., Middel, A., Urban, A., Georgescu, M., \& Sailor, D. J. (2017). Biometeorology for cities. International journal of biometeorology, 61(1), 59-69.

Höppe, P. (1999). The physiological equivalent temperature-a universal index for the biometeorological assessment of the thermal environment. International journal of Biometeorology, 43(2), 71-75.

Ionac, N., Năftănăilă, V., \& Matei, M. (2012a). Cold Waves: Meteorological Characteristics And Biometeorological Influences (Case Study: Romania, 29th January-3rd February 2012). Present Environment \& Sustainable Development, 6(2).

Ionac, N., Tăbleţ, P., \& Mihoc, A. C. (2012b). Heat waves: Meteorological characteristics and biometeorological influences (Case study: Romania, 1416TM July 2011. Present Environment \& Sustainable Development, 6(1), p181-194.

Ivanov, V., \& Evtimov, S. (2014). Heat Risks in Bulgaria during 2003-2012 period. Bulgarian Geophysical Journal, 40, 3-13.

Ivanova, V. (2016). Extreme temperatures trends in Eastern Bulgaria during the period 1959-2009. Aerul si Apa. Componente ale Mediului, 117.

Ivanova, V. (2017). Heat waves over Varna region and an opportunity for their forecasting. Varna Medical Forum, 5, 101-105. 
Fikfak, A., Kosanović, S., Konjar, M., Grom, J., \& Zbašnik-Senegačnik, M. (2017). The impact of morphological features on summer temperature variations on the example of two residential neighborhoods in Ljubljana, Slovenia. Sustainability, 9(1), 122.

Fintikakis, N., Gaitani, N., Santamouris, M., Assimakopoulos, M., Assimakopoulos, D. N., Fintikaki, M., Albanis, G., Papadimitriou, K., Chryssochoides, E., Katopodi, K. \& Doumas, P. (2011). Bioclimatic design of open public spaces in the historic centre of Tirana, Albania. Sustainable Cities and Society, 1(1), 54-62.;

Founda, D., Pierros, F., Petrakis, M., \& Zerefos, C. (2015). Interdecadal variations and trends of the Urban Heat Island in Athens (Greece) and its response to heat waves. Atmospheric Research, 161, 1-13.

Founda, D., \& Santamouris, M. (2017). Synergies between Urban Heat Island and Heat Waves in Athens (Greece), during an extremely hot summer (2012). Scientific reports, 7(1), 10973.

Jahić, H., \& Mezetović, A. (2014). Statistical identification and qualitative Evaluation of Climate tourism Potential by Using Tourism Climate Index - TCI on the Example of Herzegovina-Neretva Canton. Acta geographicaBosniae et Herzegovinae, 2, 77-89.

Johansson, E., Thorsson, S., Emmanuel, R., \& Krüger, E. (2014). Instruments and methods in outdoor thermal comfort studies-The need for standardization. Urban climate, 10, 346-366.

Joksimović, M., Gajić, M., \& Golić, R. (2013). Tourism climatic index in the valorisation of climate in tourist centers of Montenegro. Bulletin of the Serbian geographical society, 93(1).

Kántor, N., \& Unger, J. (2010). Benefits and opportunities of adopting GIS in thermal comfort studies in resting places: an urban park as an example. Landscape and Urban Planning, 98(1), 36-46.;

Kántor, N., \& Unger, J. (2011). The most problematic variable in the course of human-biometeorological comfort assessment-the mean radiant temperature. Open Geosciences, 3(1), 90-100.

Kántor, N., Égerházi, L., \& Unger, J. (2012a). Subjective estimation of thermal environment in recreational urban spaces-part 1: investigations in Szeged, Hungary. International Journal of Biometeorology, 56(6), 1075-1088.;

Kántor, N., Unger, J., \& Gulyás, Á. (2012b). Subjective estimations of thermal environment in recreational urban spaces-part 2: international comparison. International journal of biometeorology, 56(6), 10891101.

Kántor, N., Kovács, A., \& Takács, Á. (2016a). Smallscale human-biometeorological impacts of shading by a large tree. Open Geosciences, 8(1), 231-245.;
Kántor, N. (2016b). Differences between the evaluation of thermal environment in shaded and sunny position. Hungarian Geographical Bulletin, 65(2), 139-153.

Kántor, N., Kovács, A., \& Takács, Á. (2016c). Seasonal differences in the subjective assessment of outdoor thermal conditions and the impact of analysis techniques on the obtained results. International journal of biometeorology, 6o(11), 1615-1635.

Kántor, N., Chen, L., \& Gál, C. V. (2018). Human-biometeorological significance of shading in urban public spaces-Summertime measurements in Pécs, Hungary. Landscape and urban planning, 170, 241-255.

Kaplan, G., Avdan, U., \& Avdan, Z. Y. (2018). Urban heat island analysis using the landsat 8 satellite data: A case study in Skopje, Macedonia. In Multidisciplinary Digital Publishing Institute Proceedings (Vol. 2, No. 7, p. 358)

Kendrovski, V., Donev, D., Spasenovska, M., \& Kisman-Hristovska, M. Climate Change and $\mathrm{Hu}$ man Health in the Republic of Macedonia: Impacts, Vulnerability and Adaptation in Heat Wave Mortality. (2011). The European Journal of Management and Public Policy, 11(1), 71-84.

Kottek, M., Grieser, J., Beck, C., Rudolf, B., \& Rubel, F. (2006). World map of the Köppen-Geiger climate classification updated. Meteorologische Zeitschrift, 15(3), 259-263.

Kovács, A., \& Németh, Á. (2012). Tendencies and differences in human thermal comfort in distinct urban areas in Budapest, Hungary. Acta Climatologica et Chorologica, 46, 115-124.

Lai, D., Liu, W., Gan, T., Liu, K., \& Chen, Q. (2019). A review of mitigating strategies to improve the thermal environment and thermal comfort in urban outdoor spaces. Science of the Total Environment.

Lehnert, A, M., Kubeček, J., Geletič, J., Jurek, M., \& Frajer, J. (2018). Identifying hot and cool spots in the city centre based on bicycle measurements: the case of Olomouc, Czech Republic. Geographica Pannonica, 22(4), 230-240.

Lukić, M., Pecelj, M., Protić, B., \& Filipović, D. (2019). An evaluation of summer discomfort in Niš (Serbia) using Humidex. Journal of the Geographical Institute" Jovan Cvijic", SASA, 69(2), 109-122.

Malcheva, K., \& Gocheva, A. (2014). Thermal comfort indices for the cold half-year in Sofia. Bulgarian Journal of Meteorology and Hydrology, 19(1-2), 16-25. Malcheva, K. (2017). Cold waves on the territory of Bulgaria in the period 1952-2011. Bulgarian Journal of Meteorology and Hydrology, 22(3-4), 16-31.

Malinovic-Milicevic, S., Mihailovic, D. T., Lalic, B., \& Dreskovic, N. (2013). Thermal environment and 
UV-B radiation indices in the Vojvodina region, Serbia. Climate research, 57(2), 111-121.

Malltezi, J., Hanxhari, R., Zela, G., \& Sulçe, S. (2015). Climate Change Adaptation Actions in Tirana. Albanian Journal of Agricultural Sciences, 14(2), 102.

Marques, D., Lopes, A.,Bojariu, R., \& Bicu, E. A. (2015). The heat stress assessment of two contrasted outdoor urban environments: the examples of Lisbon (Portugal) and Bucharest (Romania). ICUC9 International Conference on Urban Climate, Losbon, Portugal.

Mihăilă, D., Bistricean, P. I., \& Briciu, A. E. (2019). Assessment of the climate potential for tourism. Case study: the North-East Development Region of Romania. Theoretical and Applied Climatology, 137(12), 601-622.

Milošević, D. D., Unger, J., \& Gál, T. (2015a). Thermal comfort observations in the City of Novi Sad (Serbia) in 2014. EUGEO 2015 - Convergences And Divergences Of Geography In Europe, Hungary: Budapest.

Milošević, D. D., Savić, S. M., Unger, J., \& Gál, T. (2015b). Urban climate monitoring system suitability for intra-urban thermal comfort observations in Novi Sad (Serbia)-with 2014 examples. ICUC9 - 9th International Conference on Urban Climate jointly with 12th Symposium on the Urban Environment, Portugal:Lisbon

Milošević, D. D., Savić, S. M., Marković, V., Arsenović, D., \& Šećerov, I. (2016). Outdoor human thermal comfort in local climate zones of Novi Sad (Serbia) during heat wave period. Hungarian Geographical Bulletin, 65(2), 129-137.

Milošević, D. D., Savić, S. M., \& Bajšanski, I. V. (2017a). Applications of automatic algorithms for improvement of outdoor thermal comfort in cities. Procedia engineering, 198, 187-192.;

Milošević, D. D., Bajšanski, I. V., \& Savić, S. M. (2017b). Influence of changing trees locations on thermal comfort on street parking lot and footways. Urban forestry \& urban greening, 23, 113-124.

Moustris, K., Tsiros, I. X., Tseliou, A., \& Nastos, P. (2018). Development and application of artificial neural network models to estimate values of a complex human thermal comfort index associated with urban heat and cool island patterns using air temperature data from a standard meteorological station. International journal of biometeorology, 62(7), 1265-1274.

Nastos, P. T., \& Matzarakis, A. (2012). The effect of air temperature and human thermal indices on mortality in Athens, Greece. Theoretical and Applied Climatology, 108(3-4), 591-599.

Nastos, P. T., \& Matzarakis, A. (2013). Human bioclimatic conditions, trends, and variability in the
Athens University Campus, Greece. Advances in Meteorology.

Nastos, P. T., Zerefos, C. S., Kapsomenakis, I. N., Eleftheratos, K., \& Polychroni, I. (2016). Human thermal comfort antithesis in the context of the Mediterranean tourism potential. In EGU General Assembly Conference Abstracts (Vol. 18).

Nastos, P. T., \& Polychroni, I. D. (2016). Modeling and in situ measurements of biometeorological conditions in microenvironments within the Athens University Campus, Greece. International journal of biometeorology, 6o(10), 1463-1479.

Oke, T. R., Mills, G., Christen, A., \& Voogt, J. A. (2017). Urban climates. Cambridge University Press.

Pajek, L., Tekavec, J., Drešček, U., Lisec, A., \& Košir, M. (2019). Bioclimatic potential of European locations: GIS supported study of proposed passive building design strategies. In IOP Conference Series: Earth and Environmental Science (Vol. 296, No. 1, p. 012008). IOP Publishing.

Panariti, A. T., Maliqari, A., Tashi, P., \& Islami, G. (2014). Heat Emissions of Urban Texture in Public Space. Proceedings from the ICRAE Conference, 3031 May 2014, Albania: Shkodra.

Panariti, A. T., Maliqari, A., \& Tashi, P. (2015). The Impact of Urban Texture in Outdoor Thermal Comfort. International Journal of Science and Research, 4(12), 1629-1633.

Pantavou, K., Theoharatos, G., Mavrakis, A., \& Santamouris, M. (2011). Evaluating thermal comfort conditions and health responses during an extremely hot summer in Athens. Building and Environment, 46(2), 339-344.

Pantavou, K., Theoharatos, G., Santamouris, M., \& Asimakopoulos, D. (2013). Outdoor thermal sensation of pedestrians in a Mediterranean climate and a comparison with UTCI. Building and Environment, 66, 82-95.

Papamanolis, N. (2015). The main characteristics of the urban climate and the air quality in Greek cities. Urban Climate, 12, 49-64.

Papathoma-Koehle, M., Promper, C., Bojariu, R., Cica, R., Sik, A., Perge, K., László, P., Czikora, E.B., Dumitrescu, A., Turcus, C., \& Birsan, M. V. (2016). A common methodology for risk assessment and mapping for south-east Europe: an application for heat wave risk in Romania. Natural Hazards, 82(1), 89-109.

Paravantis, J., Santamouris, M., Cartalis, C., Efthymiou, C., \& Kontoulis, N. (2017). Mortality associated with high ambient temperatures, heatwaves, and the urban heat island in Athens, Greece. Sustainability, 9(4), 606.

Pecelj, M., Pecelj, M., Cutovic, M., Pavlovic, M., Zivkovic, D., Zivkovic, L., Vujadinovic, S., Pecelj, J., 
Gajic, M. \& Mandic, D. (2011). Bioclimate weather classification of Doboj for helth spa tourism. In Proceedings of the 1oth WSEAS international conference on Artificial intelligence, knowledge engineering and data bases (pp. 292-296).

Perčič, S., Kukec, A., Cegnar, T., \& Hojs, A. (2018). Number of heat wave deaths by diagnosis, sex, age groups, and area, in Slovenia, 2015 vs. 2003. International journal of environmental research and public health, 15(1), 173.

Piticar, A., Croitoru, A. E., Ciupertea, F. A., \& Harpa, G. V. (2018). Recent changes in heat waves and cold waves detected based on excess heat factor and excess cold factor in Romania.

Pogačar, T., Črepinšek, Z., Bogataj, L. K., \& Lars, N. Y. B. O. (2017). Comprehension of climatic and occupational heat stress amongst agricultural advisers and workers in Slovenia. Acta Agriculturae Slovenica, 109(3), 545-554.

Pogačar, T., Žnidaršič, Z., Kajfež Bogataj, L., Flouris, A. D., Poulianiti, K., \& Črepinšek, Z. (2019a). Heat Waves Occurrence and Outdoor Workers' Self-assessment of Heat Stress in Slovenia and Greece. International journal of environmental research and public health, 16(4), 597.

Pogačar, T., Žnidaršič, Z., Črepinšek, Z., \& Bogataj, L. K. (2019b). Aggravated Occupational Heat Stress Recognition and Mitigation in Slovenia. In Climate Change Adaptation in Eastern Europe (pp. 267-277). Springer, Cham.

Popov, T., Gnjato, S., Trbic, G., \& Ivanisevic, M. (2018a). Recent trends in extreme temperature indices in Bosnia and Herzegovina. Carpathian Journal of Earth and Environmental Sciences, 13(1), 211-224.

Popov, T., Gnjato, S., \& Trbić, G. (2018b). Changes in Temperature Extremes in Bosnia and Herzegovina: A Fixed Thresholds-based Index Analysis. Journal of the Geographical Institute 'Jovan Cvijic' SASA, 68(1).

Popov, T., Gnjato, S., \& Trbić, G. (2019). Effects of Changes in Extreme Climate Events on Key Sectors in Bosnia and Herzegovina and Adaptation Options. In Climate Change Adaptation in Eastern Europe (pp. 213-228). Springer, Cham. DOI: 10.1007/978-3-030-03383-5_15

Porja, T. (2013). Heat Waves Affecting Weather and Climate over Albania. Journal of Earth Science and Climatic Change, 4(149), 2.

Santos Nouri, A., Costa, J. P., Santamouris, M., \& Matzarakis, A. (2018). Approaches to outdoor thermal comfort thresholds through public space design: A review. Atmosphere, 9(3), 108.

Savić, S., Milošević, D., Lazić, L., Marković, V., Arsenović, D., \& Pavić, D. (2013). Classifying urban meteorological stations sites by'local climate zones': Preliminary results for the city of Novi Sad (Serbia). Geographica Pannonica, 17(3), 60-68.

Savić, S., Selakov, A., \& Milošević, D. (2014). Cold and warm air temperature spells during the winter and summer seasons and their impact on energy consumption in urban areas. Natural hazards, 73(2), 373-387.

Savić, S., Milošević, D., Arsenović, D., Marković, V., Bajšanski, I., \& Šećerov, I. (2016). Urban climate issues in complex urbanized environments: A review of the literature for Novi Sad (Serbia). Acta Climatologica et Chorologica, 36(37), 63-80.

Savić, S., Marković, V., Šećerov, I., Pavić, D., Arsenović, D., Milošević, D.,Dolinaj, D., Nagy, I., \& Pantelić, M. (2018). Heat wave risk assessment and mapping in urban areas: case study for a midsized Central European city, Novi Sad (Serbia). Natural hazards, 91(3), 891-911.

Šećerov, I., Savić, S., Milošević, D., Marković, V., \& Bajšanski, I. (2015). Development of an automated urban climate monitoring system in Novi Sad (Serbia). Geographica Pannonica, 19(4), 174-183.

Sippel, S., \& Otto, F. E. (2014). Beyond climatological extremes-assessing how the odds of hydrometeorological extreme events in South-East Europe change in a warming climate. Climatic Change, 125(3-4), 381-398.

Skarbit, N., Stewart, I. D., Unger, J., \& Gál, T. (2017). Employing an urban meteorological network to monitor air temperature conditions in the 'local climate zones' of Szeged, Hungary. International Journal of Climatology, 37, 582-596.

Stanojević, G., Stojilković, J., Spalević, A., \& Kokotović, V. (2014a). The impact of heat waves on daily mortality in Belgrade (Serbia) during summer. Environmental Hazards, 13(4), 329-342.

Stanojević, G., Spalević, A., Kokotović, V., \& Stojilković, J. (2014b). Does Belgrade (Serbia) need heat health warning system?. Disaster Prevention and Management, 23(5), 494-507.

Takács, Á., Kiss, M., Hof, A., Tanács, E., Gulyás, Á., \& Kántor, N. (2016a). Microclimate modification by urban shade trees-an integrated approach to aid ecosystem service based decision-making. Procedia Environmental Sciences, 32, 97-109.

Takács, Á., Kiss, M., Hof, A., Tanács, E., Gulyás, Á., \& Kántor, N. (2016b). Microclimate modification by urban shade trees-an integrated approach to aid ecosystem service based decision-making. Procedia Environmental Sciences, 32, 97-109.

Teodoreanu, E. (2016). Thermal Comfort Index. Present Environment and Sustainable Development, 10(2), 105-118.

Theoharatos, G., Pantavou, K., Mavrakis, A., Spanou, A., Katavoutas, G., Efstathiou, P., Mpekas, P., \& Asi- 
makopoulos, D. (2010). Heat waves observed in 2007 in Athens, Greece: synoptic conditions, bioclimatological assessment, air quality levels and health effects. Environmental Research, 110(2), 152-161.

Trbic, G., Bajic, D., Djudjdevic, V., Crnogorac, C., Popov, T., Dekic, R., Petrasevic, A. \& Rajcevic, V. (2016). The impact of climate change on the modification of bioclimatic conditions in Bosnia and Herzegovina. International Journal of Education and Learning Systems, 1.

Trbić, G., Popov, T., \& Gnjato, S. (2017). Analysis of air temperature trends in Bosnia and Herzegovina. Geographica Pannonica, 21(2), 68-84.

Tsitoura, M., Tsoutsos, T., \& Daras, T. (2014). Evaluation of comfort conditions in urban open spaces. Application in the island of Crete. Energy conversion and management, 86, 250-258.

Unger, J., Gál, T. M., Csépe, Z., Lelovics, E., \& Gulyás, Á. (2015). Development, data processing and preliminary results of an urban human comfort monitoring and information system. IDÖJÁRÁS, 119(3),337-354

Unger, J., Skarbit, N., \& Gál, T. (2018). Evaluation of outdoor human thermal sensation of local climate zones based on long-term database. International journal of biometeorology, 62(2), 183-193.

Unkašević, M., \& Tošić, I. (2013). Trends in temperature indices over Serbia: relationships to largescale circulation patterns. International journal of climatology, 33(15), 3152-3161.

Unkašević, M., \& Tošić, I. (2015). Seasonal analysis of cold and heat waves in Serbia during the period 1949-2012. Theoretical and applied climatology, 120(1-2), 29-40.
Velea, L., Bojariu, R., Udristioiu, M. T., Sararu, S. C., Gothard, M., \& Dascalu, S. I. (2019). Assessment of summer thermal comfort using the net effective temperature index over Romania. In AIP Conference Proceedings (Vol. 2071, No. 1, p. 040004).

Vidrih, B., \& Medved, S. (2013). Multiparametric model of urban park cooling island. Urban Forestry \& Urban Greening, 12(2), 220-229.

Vitt, R., Gulyás, Á., \& Matzarakis, A. (2015). Temporal differences of urban-rural human biometeorological factors for planning and tourism in Szeged, Hungary. Advances in Meteorology.

Vučković, D., Jovic, S., Bozovic, R., Dżamić, V., \& Kićović, D. (2019). Potential of neuro-fuzzy methodology for forecasting of outdoor thermal comfort index at urban open spaces. Urban Climate, 28, 100467

Zaninović, K. (2011). Impact of extreme thermal conditions on mortality in Croatia (Doctoral dissertation), Sveučilište u Zagrebu: Prirodoslovnomatematički fakultet

Zaninovic, K. (2013). Potential of beach tourism in Croatia using climate index for tourism. In EMS Annual Meeting Abstracts (Vol. 10).

Zaninović, K., \& Matzarakis, A. (2014). Impact of heat waves on mortality in Croatia. International journal of biometeorology, 58(6), 1135-1145.;

Žiberna, I., \& Ivajnšič, D. (2018). Heat waves in Maribor between 1961-2018. Revija za geografijo-Journal for Geography, 13(2), 73-90.

Zoras, S. (2013). Urban environment thermal improvement by the bioclimatic simulation of a populated open urban space in Greece. International Journal of Ambient Energy, 36(4), 156-169. 